\title{
Efficient Heat Use from Biogas CHP Plants. Case Studies from Biogas Plants in Latvia
}

\author{
Ilze Dzene ${ }^{1}$, Lasma Slotina ${ }^{2},{ }^{1-2}$ Riga Technical University
}

\begin{abstract}
This paper focuses on efficient heat use from biogas plants. It includes an overview about various biogas heat use options and specifically addresses biogas heat use market in Latvia. In the end three examples from typical agricultural biogas plants in Latvia and their heat use plans are described.
\end{abstract}

Keywords - BiogasHeat, efficient heat use, biogas, Latvia

\section{INTRODUCTION}

In many European countries the production and use of biogas is increasingly recognized as a suitable and sustainable energy option in a renewable energy mix. Considerable developments were achieved in Germany, Austria, Czech Republic, and Denmark for the installation of agricultural biogas plants. Most plants produce electricity in combined heat and power (CHP) units. However, in many cases the heat from the CHP plant is not used efficiently. This inefficiency in energy use is a bottleneck in current biogas production, causing macroeconomic and microeconomic losses and challenges in an overall increasing land use competition [1].

The absence of heat consumers is mostly caused by the fact that biogas plants are located in agricultural areas, far away from densely populated areas. In Latvia some years ago the biogas sector started developing very rapidly. Biogas plants were able to qualify for the electricity feed-in tariff without any legal requirement to guarantee a certain efficiency level for the use of heat. Therefore the location of many biogas plants was not well planned and biogas plant operators do not have many options to find heat consumers in the vicinity of the plant.

\section{BIOGAS HEAT USE IN LATVIA}

Most of the biogas plants operating in Latvia are using biogas in CHP process thus generating both electricity and heat. Since only electricity is supported by the feed-in tariff, heat is considered as a by-product. Usually part of the heat is used on site to heat digesters and provide heating for farms and local buildings, but most of the heat is wasted.

The existing regulatory framework has not been attentive to the heat use efficiency of biogas plants. Cabinet Regulation No.262 (feed-in tariff for electricity produced from renewable energy sources) [2] does not set any requirements for biogas operators to use heat efficiently. Most of the existing biogas plants are operating and receiving their feed-in tariffs under this regulation. There are no other incentives for heat use, e.g., heat premiums or bonuses.

The only exemption is related to the feed-in tariff under Cabinet Regulation No.221 (cogeneration feed-in tariff) [3]. In order to comply with cogeneration definition and to receive rights to sell electricity within the mandatory purchase, biogas plant operators are required to prove useful heat use from their plant. In the evaluation criteria, operators can receive additional points, if at least $50 \%$ of produced heat energy that remains after the self consumption, is used effectively. Moreover, in order to qualify for the high efficiency CHP electricity feed-in tariff, the total CHP efficiency must be at least $75 \%$.

Rapid development of Latvia's biogas market has brought more competition among biogas producers for the feedstock and has increased plant operation costs. More and more biogas plant owners realize that additional income from heat use would help improve the economic performance of their plant. Few biogas plants have found a solution for useful heat utilization, e.g., greenhouse heating or using heat in drying facilities.

First attempts to use excess heat in district heating (DH) systems have been made. However, the cooperation between biogas plant owners and DH system operators is weak. DH system operators are not motivated to purchase cheaper heat from biogas plants because they are not allowed to increase their profit over 9\%. Moreover existing regulations do not allow them to purchase third party heat at a price that is below the price of resources that is needed to produce this amount of heat energy. In fact, biogas operators are not allowed to sell their heat at a lower price even if it is considered the byproduct of a biogas plant.

\section{OPTIONS FOR HEAT USE FROM BIOGAS PLANTS}

A comprehensive overview on the options for the heat use from biogas plant is provided in the Handbook on "Sustainable Heat Use of Biogas Plants" [4] developed in the BiogasHeat project that is supported by the European Commission under the Intelligent Energy Europe program. The handbook was elaborated in order to provide an overview of different options for heat use of biogas CHP units. The handbook addresses current and future biogas plant operators as well as other interested stakeholders such as policy makers, investors and students working in the field of biogas. It provides general information on the characteristics of heat produced in biogas plants and focuses on general technical solutions for the efficient use of heat.

Complementary to the handbook, the report on "Good Practice Examples for Efficient Use of Heat from Biogas Plants" [5] presents selected concepts and examples of existing biogas plants that already use waste heat.

Biogas can be converted into heat, mechanical energy, and electromagnetic energy (light). Furthermore, it can be used as 
a chemical compound. Many different options exist for use of biogas ranging from very small applications to technically sophisticated installations [4]:

- Lighting: in gas lamps;

- Heating: in biogas burners, boilers, and gas stoves;

- Drying: as a special form of heat use in charge driers, belt driers, feed-and-turn driers as well as in sorptive thermal storage systems;

- Cooling: in absorption chillers;

- Electricity: in gas engines (Pilot Injection Engines, GasOtto Engines), fuel cells, micro-gas turbines, Rankine Cycles (CRC, ORC), Kalina cycles, Stirling engines, exhaust gas turbines;

- Transport: in Compressed Natural Gas Vehicles as biomethane;

- Energy storage: in dedicated biogas storage systems (low and high pressure; liquefied) or as biomethane in the natural gas grid in order to balance electricity and heat loads;

- Natural gas substitute: upgrading to biomethane followed by injection into the natural gas grid.

The use of heat from biogas plants faces different challenges, influenced by plant characteristics. Often biogas plants are located in remote areas with no heat demand. Furthermore, the amount and quality of produced heat is often not sufficient for larger industries. Therefore, niches have to be identified in which the heat could be used in the most efficient and profitable way. The following list shows important challenges which typically characterize biogas plants [4].

- Seasonality: Less heat is needed for heating the digesters in summer. Furthermore, certain heating applications, e.g. of buildings, are only needed in winter. Thus, there is often a heat surplus in summer.

- Remoteness: Especially agricultural biogas plants are often situated in remote rural areas where no heat consumers (e.g. small industries, public buildings) are located.

- Heat quality and quantity: The installed capacity of typical agricultural biogas plants in Europe is about $500 \mathrm{kWth}$, which is too small for the use of heat by larger industries. Some industries require higher temperatures than the ones that can be provided by a biogas plant.

- Economic risks: Biogas plant operators who "depend" on external heat consumers may face economic risks in case of changing demand. Long-term contracts can help to mitigate this risk.

- High costs: Several options for using waste heat require additional equipment with high investment costs, for example the installation of ORC modules or the set-up of micro-heating grids.

- Public acceptance and support: The set-up of new microheating-grids is only possible if the heat demand is ensured, meaning that enough customers need to be willing to get connected. Furthermore, local administrations need to lend their support to allow the construction of microheating-grids.
- Fossil fuel prices: The use of waste heat from biogas plants has to be competitive with the prices of fossil fuels and other renewable energy sources.

The use of waste heat from CHP units is a crucial factor for the economic and environmental performance of biogas plants. It has to be economically and technically feasible. If the application of a sound heat concept is not possible, other solutions such as upgrading and biomethane grid injection or the installation of biogas pipelines have to be considered. In many cases it is better to give up plans for a biogas plant project if no acceptable concept for heat use can be developed [4].

If planned well and enough in advance, however, heat concepts can be developed for most biogas plants. The more flexible the framework conditions are, the more options for the use of waste heat are available. These framework conditions include conditions such as the location of the plant, potentially interested heat consumers, legal issues, liquidity, and others.

The main product of biogas CHP plants is power which is usually fed into the electricity network. The main challenge is the sustainable use of the heat. It can generally be used directly for heating, but also for additional power production, cooling, or for drying (see Figure 1).

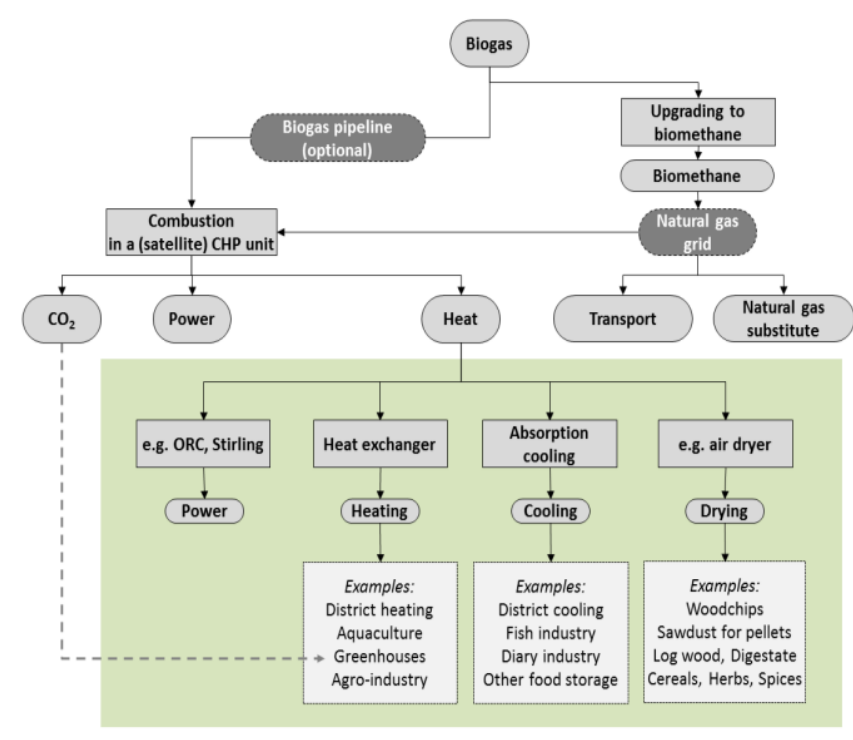

Fig. 1. Simplified flowchart for the use of biogas [6]

\section{IV.CASE STUDIES FROM BIOGAS PLANTS IN LATVIA}

There are around 40 biogas plants currently operating in Latvia. Most of the plants are qualified for receiving the electricity feed-in tariff. Feed-in tariff in Latvia is given for the electricity that is generated from renewable energy sources (Cabinet Regulation No.262) and for the electricity generated in high efficiency CHP plants (Cabinet Regulation No.221). Biogas plant operators can choose under which regulation to apply. Most of the plants are operating under Regulation No.262 where efficient heat use is not a requirement. Plants that are operating under Regulation No.221 are subject to heat use efficiency requirements. 
Biogas plants that were constructed without being obliged to use heat efficiently have already come to the point where efficient heat use is necessary for the overall economical feasibility of the biogas plant.

Interviews conducted with biogas plant operators in Latvia during the BiogasHeat project [7] indicate that the only driver for introduction of heat use solutions at the biogas plant is economic. Biogas plant owners are thinking about how to use heat efficiently only because it has a great effect on the economical feasibility of the overall economics of the biogas plant.

Main barriers for introduction of heat use solutions in biogas plants in Latvia are:

- Higher investment costs for the biogas plant if heat use solution is constructed together with the biogas plant.

- Since efficient use of heat is not required as an obligatory measure in legislation, putting additional investment into the heat use solution upon inception might be considered as an unnecessary extra cost (as well commercial banks might not be willing to add this extra costs to the loan).

- In the beginning it is not clear how much gas will be generated under the real operation regime and accordingly it is difficult to predict the necessary parameters of the potential heat consumer.

Existing biogas plant operators are appreciating more and more the necessity to find useful utilisation of heat and some good examples already exist.

\section{A. Case study 1: "Ekorima" biogas plant}

„Ekorima” biogas plant is located in Krimuldas region Lēdurgas district „Veckḷavinas”. The biogas plant is operated since 2012 with $0.95 \mathrm{MW}_{\mathrm{el}}$ and $1.080 \mathrm{MW}_{\text {th }}$ installed capacity. It has two digesters and uses 32,000 tons of feedstock. As feedstock cow manure $-16,000$ tons, maize silage $-15,000$ tons and grass silage is used. 16,000 tons of cattle manure are delivered daily from a neighborhood farm that produces milk and meat. Annual electricity production is 7,500 $\mathrm{MWh}_{\mathrm{el}}$ and annual heat production is $8500 \mathrm{MWh}_{\mathrm{th}}$. Electricity, which is produced by the biogas plant is fed into the electricity transmission and distribution grid. The heat is used for drying wood in drier and heating the cattle farm. Figure 2 shows firewood, which is prepared for the drying process.

After the drying process, the firewood is packed and exported to several countries around the world. The drying process consumes 7,200 $\mathrm{MWh}_{\mathrm{th}}$ of total heat production.

\section{B. Case study 2: "Agro lecava" biogas plant}

"Agro Iecava” biogas plant is located in Iecava „Latvall Jaunlūči”. The biogas plant started operating in 2011 with power and heat capacity of $1.95 \mathrm{MW}_{\mathrm{el}}$ and $2.48 \mathrm{MW}_{\mathrm{th}}$, respectively. The biogas plant has input of 25,000 tons of grass silage, 20,000 tons of poultry manure and grass, residues from dairy and grain. In 2012, the biogas plant generated $14,040 \mathrm{MW}_{\mathrm{el}}$ of electricity [8]. Electricity, which is produced by Agro Iecava is fed into the electricity grid. The use of heat that has been produced in the biogas plant for external purposes started in November 2011, when the biogas plant owner installed a biogas pipeline from the plant to the residential area Iecava. This way it was possible to use heat from biogas plant in the district heating system of Iecava village. In 2012 more than $8,190 \mathrm{MWh}_{\mathrm{th}}$ were sold to the district heating consumers. As a result of the use of biogas, the heat tariff for residents was reduced by $17 \%$. The new task of the biogas plant operator is to find heat use for the surplus heat in summer when the heat demand of the district heating system is very low. Currently there is a plan to use heat for drying.

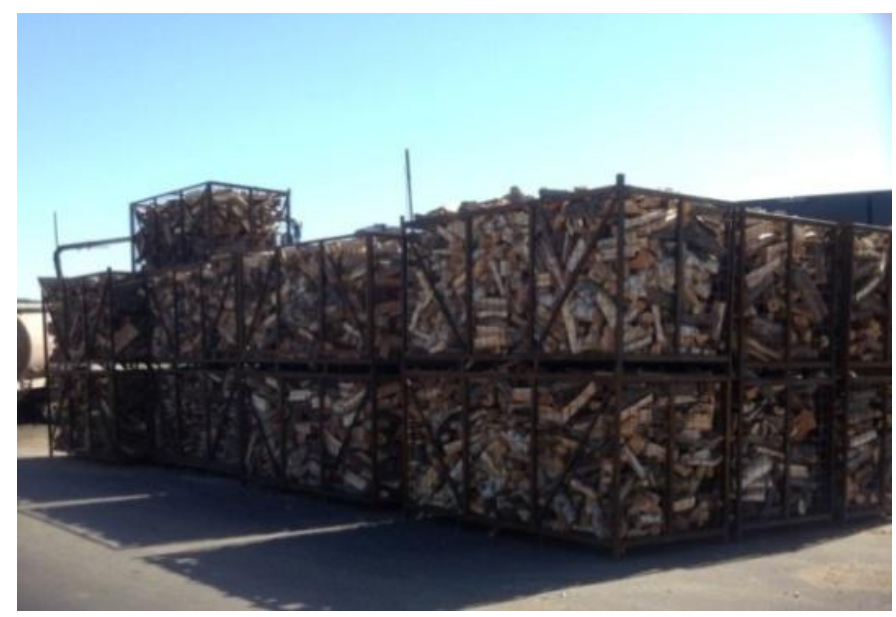

Fig. 2. Firewood, which is ready to drying process

\section{Case study 3: "Bio Ziedi" biogas plant}

"Bio Ziedi" biogas plant is located in Dobele region Dobele district Aizstrautnieki „Kalna Oši” and has been in operation since the beginning of 2011. The photo of the biogas plant is provided in Figure 3.

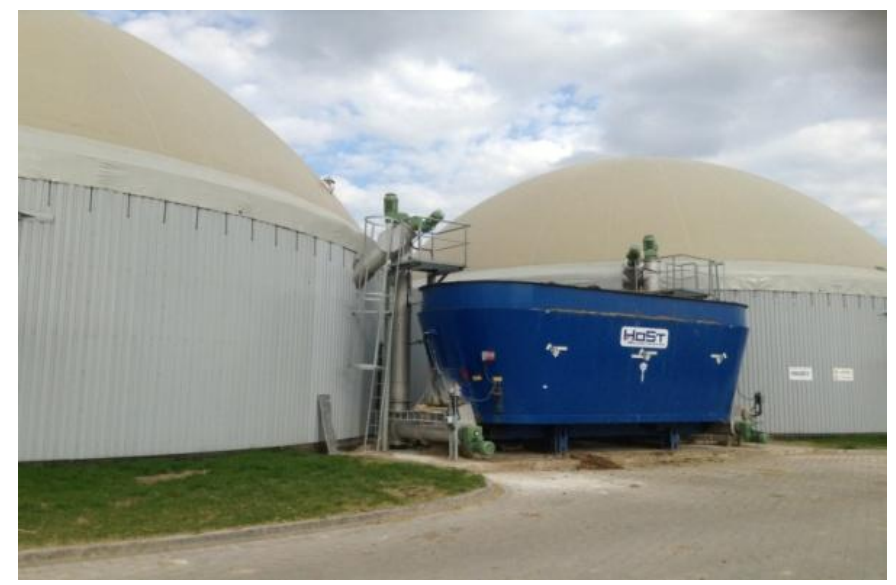

Fig. 3. „Bio Ziedi“ biogas plant

The biogas plant uses 54,500 tons of feedstock, which consist of cow manure, grass and corn. Cow manure is daily delivered from a farm located in the vicinity of the biogas plant. The farm breeds 2,300 cows. The capacity of the "Bio Ziedi" biogas plant is $1.98 \mathrm{MW}_{\mathrm{el}}$ and $4 \mathrm{MW}_{\mathrm{th}}$. Around 16,000 $\mathrm{MWh}_{\mathrm{el}}$ of electricity is generated annually. Electricity is fed into the general transmission and distribution grid. Annual heat production is $32,000 \mathrm{MWh}_{\mathrm{th}}$. Currently it is used to heat 
digesters and the farm. In the future there is a plan to also use heat for heating a cannery and aquaculture.

\section{CONCLUSIONS}

Lately, biogas technology is one of the most actively developing technologies in Latvia. In comparison with ten years ago, the technology has rapidly entered the market. In Latvia this technology is already over the pilot stage and now there is experience and knowledge, which is an important factor in making it possible to review and draw analysis from this experience.

Accumulated experiences show that biogas plant operators have underestimated the expected biogas outcome and many plant operators have faced a problem that the actual biogas amount is far less than desired. The installed capacity also should have been chosen more carefully at the design stage and based on more realistic assumptions.

Economical drivers are most important for the biogas plant owners. Heat use solutions will be implemented only when it will be economically feasible and will bring additional benefit for the overall economical feasibility of the biogas plant. When heat use requirements are defined by the legislation, it is easier to justify higher initial investment required for building the biogas plant with already integrated heat use concept.

\section{ACKNOWLEDGMENT}

This paper is prepared with the support of the BiogasHeat project (Development of sustainable heat markets for biogas plants in Europe). The BiogasHeat project is supported by the European Commission in the Intelligent Energy for Europe Programme. The sole responsibility for the content of this paper lies with the authors. It does not necessarily reflect the opinion of the European Union. Neither the EACI nor the European Commission is responsible for any use that may be made of the information contained therein. The BiogasHeat project duration is from April 2012 to April 2015 (Contract Number: IEE/11/025).

\section{REFERENCES}

1. Dzene, I., Rochas, C., Rutz, D., et.al. Development of Sustainable Heat Markets for Biogas Plants in Europe. Proceedings of $20^{\text {th }}$ European Biomass Conference and Exhibition, Milan, Italy, 18-22 June, 2012, p.2456-2462.
2. Cabinet Regulation No.262 "Noteikumi par elektroenerǵijas ražošanu, izmantojot atjaunojamos energoresursus, un cenu noteikšanas kārtỉbu" ("LV", 51/52 (4243/4244), 31.03.2010) [16.03.2010, in force since 01.04.2010].

3. Cabinet Regulation No.221 "Noteikumi par elektroenerǵijas ražošanu un cenu noteikšanu, ražojot elektroenerǵiju koǵenerācijā" ("LV", 42 (4028), 17.03.2009) [10.03.2009, in force since 18.03.2009].

4. Sustainable Heat Use of Biogas Plants. A Handbook. D.Rutz, R.Mergner, R.Janssen. WIP Renewable Energies: Munich, Germany, 2012.

5. Ramanauskaite, R., Rutz, D., Bailon L., et.al. Good Practice Examples for Efficient heat Use from Biogas Plants. - WIP Renewable Energies: Munich, Germany, 2012.

6. University of Florida. Biogas Use. Available: http://biogas.ifas.ufl.edu [Accessed: 12.09.2013]

7. BiogasHeat project No.IEE/11/025. Available: www.biogasheat.org (2012) [Accessed: 12.09.2013]

8. Ministry of Economy, Electricity supplied to the network in 2012.

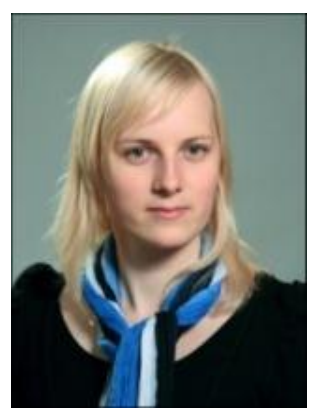

Ilze Dzene, Dr.sc.ing., has a diploma in computer science and information technology (2003), master of science degrees in information technology (2005) and environmental science (2007). She has obtained a doctor degree in environmental engineering in 2011. She works in the Institute of Energy Systems and Environment, Faculty of Electrical and Power Engineering, Riga Technical University from the year 2005, and currently is docent and researcher. Ilze Dzene is also working as a Project Manager for the energy consulting company Ekodoma. Her main research interests are related to sustainable energy planning, integration of renewable energy sources in energy systems, biogas and efficiency of biogas plants. Ilze Dzene is a member of the Latvian Biogas Association.

Address: Kronvalda boulev.1, LV1010, Riga, Latvia

E-mail: ilze.dzene@rtu.lv

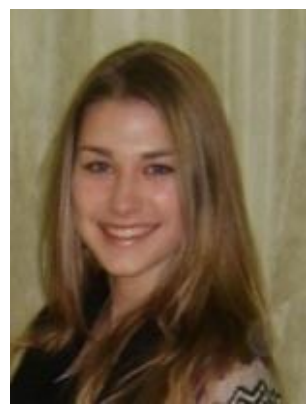

Lāsma Slotina, B.sc., has a Bachelor degree in Environmental Engineering from Riga Technical University (Faculty of Power and Electrical Engineering) her thesis was: „Efficient energy use of biogas plants”. Lāsma started working for Ekodoma Ltd in June 2013 as a project assistant. Lāsma works in projects related to use of biomass and biogas. Lāsma is a member of the Environmental Science Students Association of Latvia, were she was organizing several discussions and projects about efficient use of energy and use of alternative energy.

Address: Kronvalda boulev.1, LV1010, Riga, Latvia

E-mail: lasma.slotina_3@rtu.lv 